\title{
Buffer zone use by mammals in a Cerrado protected area
}

\author{
Roberta Montanheiro Paolino ${ }^{1,3}$, Natalia Fraguas Versiani ${ }^{1}$, Nielson Pasqualotto ${ }^{1}$, \\ Thiago Ferreira Rodrigues ${ }^{1}$, Victor Gasperotto Krepschi ${ }^{2}$ \& Adriano Garcia Chiarello $^{1}$ \\ ${ }^{1}$ Universidade de São Paulo, Faculdade de Filosofia, Ciências e Letras, Departamento de Biologia, Av. \\ Bandeirantes, 3900, 14040-901, Bairro Monte Alegre, Ribeirao Preto, SP, Brasil. \\ ${ }^{2}$ Universidade Estadual Paulista "Júlio de Mesquita Filho", Instituto de Biociências, Departamento de \\ Ecologia, Rua 24A, 1515, 13506-900, Bairro Bela Vista, Rio Claro, SP, Brasil. \\ ${ }^{3}$ Corresponding author: Roberta Montanheiro Paolino, e-mail: paolinorm@usp.br
}

PAOLINO, R.M., VERSIANI, N.F., PASQUALOTTO, N., RODRIGUES, T.F., KREPSCHI, V.G., CHIARELLO, A.G. Buffer zone use by mammals in a Cerrado protected area. Biota Neotropica. 16(2): e20140117. http://dx.doi.org/10.1590/1676-0611-BN-2014-0117

\begin{abstract}
Habitat loss and degradation is threatening mammals worldwide. Therefore, Protected Areas (PA) are of utmost importance to preserve biodiversity. Their effectiveness, however, depends on some management strategies such as buffer zones, which prevent/mitigate the impact of external threats and might increase the amount of available habitat for wildlife existing within reserves. Nevertheless, how intensively terrestrial mammals use buffer zones remains little studied, particularly in the Neotropical region. Aiming to analyse the use of a buffer zone ( $5 \mathrm{~km}$ wide) by medium and large-sized mammals, we modelled the occupancy probabilities of five species of conservation concern including local (interior and buffer zone) as a site covariate, simultaneously controlling for imperfect detection. Data collection was made with camera traps from April to September 2013 in a 9000 ha Cerrado PA ("interior") and in its surrounding area (39721.41 ha; "buffer zone"). This PA (Jataí Ecological Station) is immersed in a landscape where sugarcane plantations predominate in the northeastern of the state of São Paulo. We also conducted an inventory to compare the number and composition of species between interior and buffer zone. A total of 31 mammal species (26 natives) was recorded via camera traps and active search for sightings, vocalizations, tracks and signs. Occupancy estimates for Myrmecophaga tridactyla, Leopardus pardalis and Pecari tajacu were numerically higher in interior. On the other hand, Chrysocyon brachyurus had the highest occupancy in buffer zone, while the largest predator, Puma concolor, used both areas similarly. However, as the confidence intervals $(95 \%)$ overlapped, the differences in occupancy probabilities between interior and buffer were weak for all these species. Additionally, regarding only the species recorded by cameras, the observed and estimated richness were similar between interior and buffer zone of the PA. Our data demonstrated that the buffer zone is indeed used by medium and large-sized mammals, including conservation-dependent ones. The lack of enforcement of current legislation regarding buffer zones is therefore a real threat for mammals, even when protection is guaranteed in the interior of protected areas.
\end{abstract}

Keywords: Medium and large-sized mammals, camera trapping, detection probability, occupancy, Jatai Ecological Station.

PAOLINO, R.M., VERSIANI, N.F., PASQUALOTTO, N., RODRIGUES, T.F., KREPSCHI, V.G., CHIARELLO, A.G. Uso da zona de amortecimento de uma Unidade de Conservação de Cerrado por mamíferos. Biota Neotropica. 16(2): e20140117. http://dx.doi.org/10.1590/1676-0611-BN-2014-0117

Resumo: A perda e degradação de habitat têm ameaçado os mamíferos no mundo todo. Dessa forma, a criação de Unidades de Conservação (UC) faz-se cada vez mais fundamental para sua preservação. Entretanto, estratégias de manejo são necessárias para que as UCs cumpram plenamente seus objetivos, tal como o estabelecimento de uma zona de amortecimento ao seu redor, a qual aumenta a área de habitat protegido e visa servir como barreira a impactos negativos externos. Contudo, o uso das zonas de amortecimento por mamíferos terrestres permanece pouco estudado, particularmente no Neotrópico. Com o objetivo de analisar o uso de uma zona de amortecimento ( $5 \mathrm{~km}$ de extensão) por mamíferos de médio e grande porte, nós modelamos a probabilidade de ocupação de cinco espécies de interesse conservacionista, incluindo local (interior e zona de amortecimento) como uma covariável de sítio, controlando, simultaneamente, as imperfeições na detecção. Os dados foram coletados por meio de armadilhamento fotográfico de abril a setembro de 2013 em uma UC de Cerrado de 9000 ha e em 
39721,41 ha do seu entorno. A área de estudo (Estação Ecológica de Jataí) está imersa em uma paisagem de matriz canavieira no nordeste do estado de São Paulo. Nós também realizamos um inventário a fim de comparar a riqueza e a composição de espécies no interior e na zona de amortecimento. Foi registrado um total de 31 espécies (26 nativas), incluindo aquelas amostradas apenas por identificação de vestígios, de vocalizações e por observação direta. As estimativas de ocupação para Myrmecophaga tridactyla, Leopardus pardalis e Pecari tajacu foram numericamente maiores no interior, enquanto Chrysocyon brachyurus obteve a maior estimativa de ocupação na zona de amortecimento. Já o maior predador, Puma concolor, utilizou ambas as áreas de forma semelhante. Entretanto, como houve sobreposição entre os intervalos de confiança (95\%), as diferenças nas probabilidades de ocupação entre interior e zona de amortecimento foram fracas para as cinco espécies analisadas. Além disso, considerando apenas as espécies registradas por armadilhamento fotográfico, a riqueza observada e a estimada foram similares no interior e na zona de amortecimento da UC. Nossos dados demonstraram que a zona de amortecimento é de fato utilizada por várias espécies de mamíferos de médio e grande porte, incluindo aquelas prioritárias para a conservação. Portanto, a falta de cumprimento da legislação vigente em relação às zonas de amortecimento é uma ameaça real para as espécies de mamíferos, mesmo quando a proteção é garantida no interior das UCs.

Palavras-chave: Mamíferos de médio e grande porte, armadilha fotográfica, probabilidade de detecção, ocupação, Estação Ecológica de Jataí.

\section{Introduction}

The persistence of several species worldwide has been threatened by current levels of anthropogenic disturbances in natural environment to the point that the rate of species extinction is already comparable to mass extinction events of the geological past (Dirzo et al. 2014). Among mammals, one in each four species is already threatened, mainly due to habitat loss and degradation. Furthermore, the effect of hunting or gathering species for food, medicines or fuel in natural areas of the Neotropics affect $64 \%$ of the large-bodied mammals, which have large home ranges and depend on a large amount of area to maintain viable populations (Schipper et al. 2008). However, the maintenance of large natural areas depends primarily on public policies that regulate land use and protection, together with community commitment (Watson et al. 2014).

The replacement of native vegetation by agriculture, pastures and urban areas is a top concern in the Neotropics, where deforestation rates are high (Schipper et al. 2008). In Brazil, notwithstanding its conservation importance, the Cerrado has already lost between $48 \%$ and $55 \%$ of its original area (Klink \& Machado 2005; IBGE 2010). This domain is the most biodiverse savannah in the world (Klink \& Machado 2005), comprising 251 mammalian species, 31 of which are endemic (Paglia et al. 2012). It is thus considered a biodiversity hotspot and a priority region for conservation (Myers et al. 2000). Nevertheless, there is a relatively small number of Cerrado protected areas, which covers only $4.1 \%$ of its original area (Klink \& Machado 2005).

Protected areas (PA) are recognized as the most effective strategy for in situ conservation, maintaining not only the biodiversity and ecosystem services, but also historical and cultural values (Chape et al. 2005, Xavier et al. 2008). However, the conservation of viable populations in the long term inside PA depends on their surroundings, since species are not restricted to the interior of the reserves (Hjert 2006, Vynne et al. 2014). Thus, the establishment of buffer zones around them are important management strategies for adequately achieving the objectives of a PA, as well as to mitigate isolation problems (Morsello 2001).

A buffer zone is defined as the immediacy of a PA where the land uses are subjected to specific norms and restrictions in order to protect and increase the conservation value of a PA (Lynagh
\& Urich 2002), providing supplementary habitat and resources for larger wild animal populations (Morsello 2001). The establishment of a buffer zone prevents and/or mitigates direct and indirect anthropogenic-derived impacts from outside of the PA such as fire, erosion, alien species invasion, noise disturbance and edge effects (Vitalli et al. 2009, Vynne et al. 2014). Moreover, this strategy contributes to avoid that the immediate surroundings of a PA act as ecological traps for wildlife (i.e., road kills, trapping and poaching) (van der Meer et al. 2015). Additionally, buffer zones have the potential to mitigate conflicts between local communities and wildlife (Hjert 2006).

Many species of medium and large-sized mammals use both the interior of PA and its surroundings as part of their home range such as Chrysocyon brachyurus, Puma concolor and Leopardus pardalis (Mantovani 2001). The buffer zone is suitable habitat for several species, even though there are cases in which animal abundances decrease from the PA perimeter towards the buffer zone limit because of the concomitant increase of human activities and occurrence of domestic animals (Jotikapukkana et al. 2010). Mantovani (2001) and Jotikapukkana et al. (2010) are some of the very few studies that assess the occurrence of wildlife in buffer zones and the importance of these areas (Massara et al. 2012). Furthermore, the Brazilian law on buffer zones lacks clarity and objectivity that hamper their practical application (Vitalli et al. 2009). The establishment of biologically meaningful and efficient buffer zones is an intricate issue further complicated by lack of information derived directly from wildlife studies occurring in this zones (Tambosi 2008).

In order to improve the knowledge of species use of buffer zones, occupancy modeling based on camera trap data can be used to compare the occurrence of a given species among different sites such as the interior and the buffer zone of a PA (Mackenzie et al. 2002, Bailey et al. 2004, O’Connell 2011). This approach has the differential of dealing with imperfect detection, because individuals may not be detected due to sampling limitations or low population density, which is common issue for several species of medium and large-sized tropical mammals (Mackenzie et al. 2002, O'Connell et al. 2006). Furthermore, occupancy models are a powerful tool to analyze the influence of landscape covariates and habitat changes on species occurrence (Nicholson \& Manen 2009, Cove 2011). 
Hence, this study analyse the use of a buffer zone by five species of conservation concern through occupancy modelling, assessing whether these species are using similarly interior and buffer zone of a Cerrado PA. Additionally, we compare species richness and composition of medium and large-sized mammals between interior and buffer zone of the UC. We expected that (1) species would use the buffer zone, but less than the interior of the $\mathrm{PA}$; and that (2) richness in the interior of the PA would be higher than in the buffer zone.

\section{Materials and Methods}

\section{Study Area and Landscape Characterization}

This study was carried out in the Jataí Ecological Station (JES; 9013 ha) and in the Luiz Antônio Experimental Station (LAES; 2009 ha), which are adjacent to each other (Figure 1). These two areas are located in the Luiz Antônio municipality, in the northeastern portion of the state of São Paulo $\left(21^{\circ} 30^{\prime} \mathrm{S}, 47^{\circ}\right.$ $\left.50^{\prime} \mathrm{W}\right)$. According to Köppen classification, the climate of this area is Aw (tropical humid) (CEPAGRI 2014). The predominant vegetation in JES is the Cerradão (wooded Cerrado; $60.7 \%$ ), followed by areas of Cerrado in regeneration $(19.5 \%)$ and Atlantic Semi-deciduous forest (13.6\%) (Toppa 2004).

Land use and land cover map classification of the PAs (JES and LAES) and their buffer zone (Figure 1) were done in a
1:20000 scale, based on ortophotomosaics from IGC (Instituto Geográfico e Cartográfico do Estado de São Paulo) and field data, using QuantumGIS 2.2.0 and ArcGIS 10.1 (ESRI 2002). We defined the buffer zone as a $5 \mathrm{~km}$ buffer around the perimeter of JES and LAES following the definition given by JES Management Plan (Leonel et al. 2010). In addition, as camera traps were placed up to $2.6 \mathrm{~km}$ away from the perimeter of JES and LAES (Figures 1 and 2) and considering that some medium and large-sized mammals have large home ranges (Mantovani 2001, Oliveira 1994), the $5 \mathrm{~km}$ buffer includes the influence zone of the outermost points sampled. Therefore, our $5 \mathrm{~km}$ buffer comprises almost all, and surpasses in parts, the "official" buffer zone of JES. For this reason, we discuss our results as representative of the buffer zone of this reserve.

We made an accuracy analysis (Kappa concordance analysis) of our map of land cover type and use by comparing the final map with Google Earth images and the achieved overall accuracy was of $90 \%$. Our mapping showed that the whole study area (50744.1 ha: JES + LAES $+5 \mathrm{~km}$ buffer) is mainly covered by sugarcane plantations $(40.6 \%)$, followed by native vegetation (Cerradão, Cerrado stricto sensu, Semi-deciduous Atlantic forest, Deciduous Atlantic forest and riverine forests), which covers about a third of this area (Table 1). Examining separately PA and the buffer zone, however, we see a contrasting scenario. While the interior of these two PA are mainly covered by native vegetation $(77.3 \%)$, only $13.2 \%$ of the buffer zone

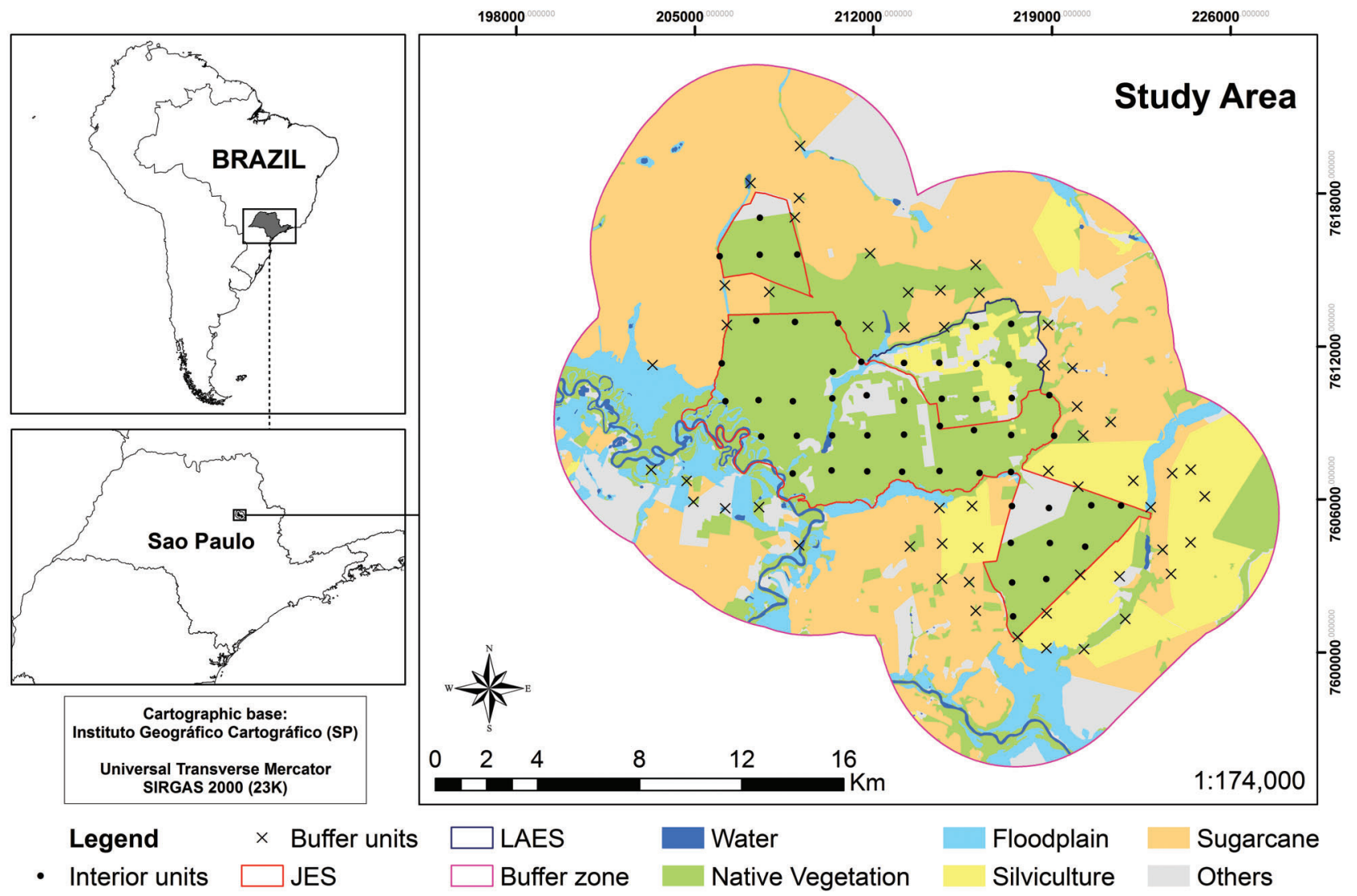

Figure 1. Location and limits of the study areas in the state of São Paulo, Brazil: Jataí Ecological Station (JES), Luiz Antônio Experimental Station (LAES) and their buffer zone ( $5 \mathrm{~km}$ from the perimeter of the reserves). The land use and cover map (1:20000) is illustrated for the entire study area with the location of sampling units (52 in interior and 53 in buffer zone). Cartographic bases: Instituto Florestal do estado de São Paulo and IBGE (2008). Projection: Transverse Mercator. Datum: SIRGAS 2000. 


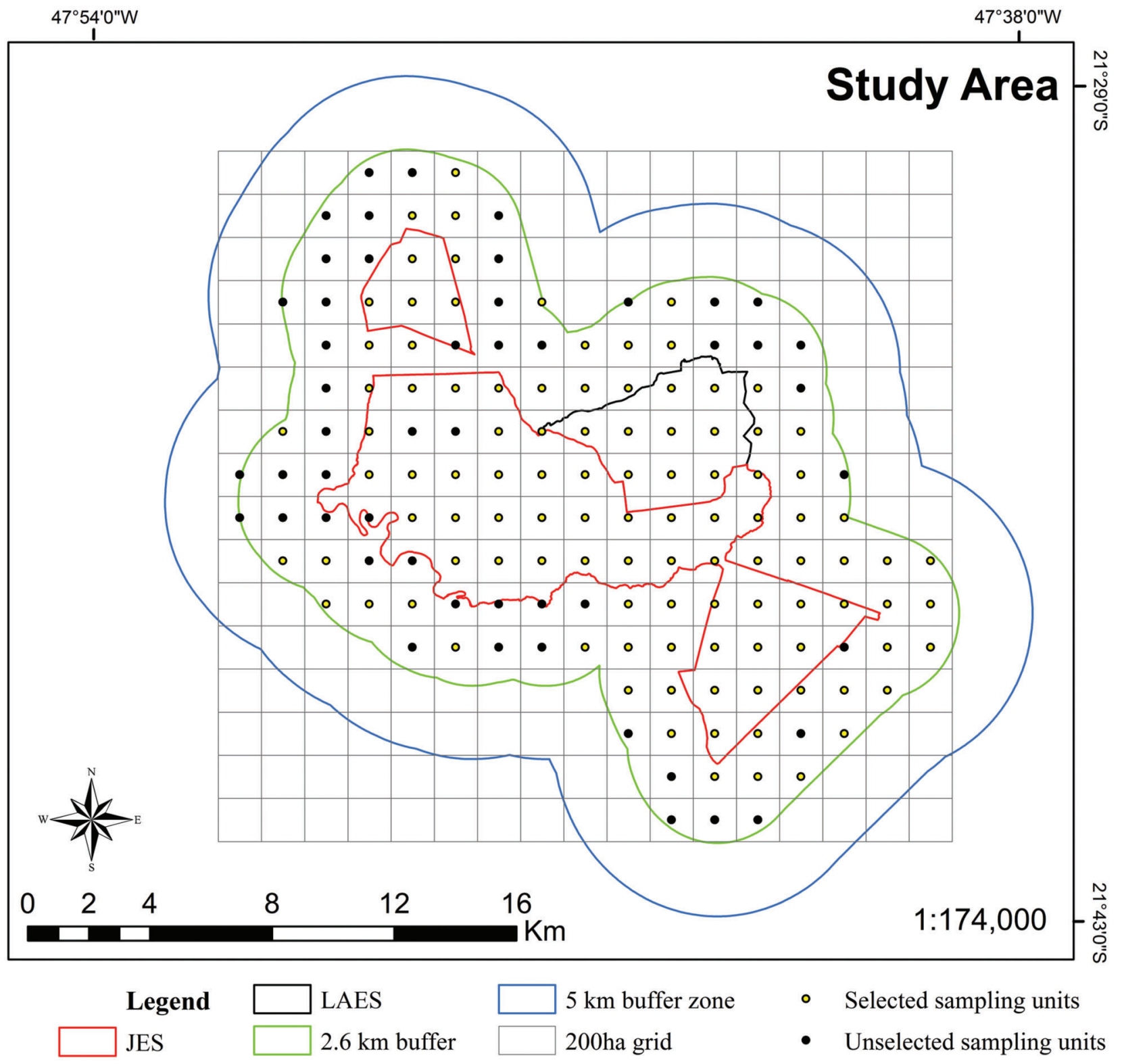

Figure 2. Sampling design of this study with the limits of the study areas (JES = Jataí Ecological Station; LAES = Luiz Antônio Experimental Station), the $2.6 \mathrm{~km}$ buffer, the $5 \mathrm{~km}$ buffer zone, the grid of 200 ha squares and the potential and selected sampling units.

retains native vegetation. Sugarcane is, by far, the predominant land cover type in the buffer zone $(51.8 \%)$, followed by silviculture (Pinus spp. and Eucalyptus spp.; 13.5\%). Nonetheless, it is important to highlight that although the buffer zone is predominantly "anthropic", the amount of natural habitats remaining in the buffer zone (native vegetation plus floodplains) is quite significant (9322 ha) (Figure 1 and Table 1).

\section{Camera trapping and Data collection}

We surveyed mammals in the study area using camera traps (Reconyx ${ }^{\circledR}$, digital model HC 500) and active search for signs (footprints, scats, scratches) during the 2013 dry season (AprilSeptember). We restricted the inventory to only one season aiming to satisfy the closure assumption in single-season occupancy studies (no extinction and colonization of our study species at sampling points during our "sampling season") (Mackenzie et al. 2006). We distributed camera traps (sampling points) overlying a grid of square cells (200 ha each or $1.4 \times 1.4 \mathrm{~km}$ wide) over the study area. The center of each square was a potential point for sampling. Within the JES and LAES, we sampled 52 of the 54 squares that covered the entire area of these two reserves (Figure 2). We discarded two cells because they were inaccessible. Since the buffer zone is a much larger area than the interior, we randomly sampled 53 squares from the total of 97 squares available (Figure 2). Thus, we divided our sampling effort similarly between interior and buffer. Given logistical and safety issues, all randomly selected points in sugarcane plantations or pasture were relocated to the nearest available native vegetation, where cameras were oriented to aim at the originally chosen land cover type (either sugarcane or pasture). In some cases, we placed the camera as close as possible to the original point because we 
Table 1. Landscape characterization (hectares and \%) within the protected areas (JES and LAES: "interior") and outside these protected areas ("5 km buffer zone"). We also show the landscape represented by the area of influence of each camera trap location (the 200 ha surrounding all sampled points $=$ "camera traps"). Native vegetation = Cerradão, Cerrado stricto sensu, Atlantic Semi-deciduous, deciduous and riverine forests; Silviculture = Pinus spp. and Eucalyptus spp.; Others = Water, Grassland, Regenerating area, Orange plantation, Pasture and Urban areas.

\begin{tabular}{llcccrr}
\hline & Area (ha) & Native Vegetation (\%) & Floodplain (\%) & Sugarcane (\%) & Silviculture (\%) & Others (\%) \\
\hline Interior & 11021.91 & 77.31 & 2.64 & 0.00 & 5.38 & 14.61 \\
5 km buffer & 39722.19 & 13.24 & 10.23 & 51.83 & 13.51 & 11.20 \\
Total & 50744.10 & 27.16 & 8.58 & 40.57 & 11.74 & 11.94 \\
Camera traps & 21006.74 & 46.56 & 5.53 & 21.02 & 16.62 & 10.27 \\
\hline
\end{tabular}

were unable to access the exact location of all sampling points. Thus, the average minimum distance between two adjacent points was $1.31 \mathrm{~km}$ for the interior and $1.15 \mathrm{~km}$ for the buffer.

Every month, 18 camera traps were placed in the study area. For each sampling point, a single camera trap was set on a tree trunk $40-60 \mathrm{~cm}$ above the ground and programmed to monitor continuously (24hd) during 30 consecutive days, recording date and time of each photograph. Due to some logistical problems, 105 of 108 sampling points were sampled, totalling an effort of 3150 camera trap days, half of which in JES/LAES and half in the buffer zone. There were no relevant differences in sampling effort between camera traps since $98 \%$ of them worked on average 30 days (average sampling effort $=$ 29.8 days, $\mathrm{SD}=0.76$ ).

The 105 sampled points were distributed in native vegetation $(62.9 \%)$, silviculture $(20 \%)$, sugarcane $(5.7 \%)$ and in other land cover types $(11.7 \%)$. Thus, the land cover represented by the exact location of cameras differed from the percentage of area covered by each land type in the whole landscape (Table 1). However, this contrast is smaller when we consider the landscape inside the 200 ha circle surrounding all camera trap locations (Table 1).

During the setup and removal periods, we actively searched for mammal tracks, walking $200 \mathrm{~m}$ in unpaved roads existing nearest to each camera trap station, totalling $21 \mathrm{~km}$ of sampling throughout the entire study. The data collected during the active searches for signs, direct observation and vocalizations was complementary to the inventory. We photographed signs and footprints and identified the species with the help of field guides (Becker \& Dalponte 1999, Borges \& Walfrido 2004, Carvalho Jr. \& Luz 2008, Mamede \& Albo 2008, Moro-Rios et al. 2008, Miranda et al. 2009).

\section{Data analysis}

For comparative purposes, the pool of medium and largesized mammal species that could possibly occur in the region was compiled based on the current Checklist of Brazilian Mammals (Paglia et al. 2012), together with other general sources of information for mammals (Emmons \& Feer 1997, Eisenberg \& Redford 1999, Kasper et al. 2009, IUCN 2014), and also from Mammalian Species (www.asmjournals.org/loi/ mmsp). The resulting list totalled 39 species of medium to large-sized mammals (approximately $\geq 2 \mathrm{~kg}$ ) with terrestrial or scansorial habit. Since our sampling methods did not represent arboreal species (primates, sloths and porcupines), these were not included in statistical analyses. Moreover, occupancy modelling and analysis of species richness were carried out using solely camera trapping data.

Among the recorded species, we selected five to model occupancy and detection probabilities (Mackenzie et al. 2006) in order to assess if they were occupying differently the interior of the PA and the buffer zone. Selection of the species was based on their conservation status and habitat requirements. The selected species included the top predator still extant in the region, the puma (Puma concolor), a mesopredator, the ocelot (Leopardus pardalis), a large omnivore, the maned wolf (Chrysocyon brachyurus), a large frugivore, the collared peccary (Pecari tajacu), and a large myrmecophage, the giant anteater (Myrmecophaga tridactyla). All these species are threatened with extinction in the state of São Paulo (classified as Vulnerable), except the collared peccary, which is classified as Near Threatened (Bressan et al. 2009).

We organized presence data into detection/non detection matrices, one for each species, considering six sampling occasions of five days each (6 occasions x 5 days $=30$ days). We modelled occupancy $(\psi)$ and detection (p) probabilities of each species in MARK 8.0 (White \& Burnham 1999), assessing the effect of explanatory variables. It is important to assess detection to improve the estimation of the key parameter of interest here $(\psi)$. We choose one site covariate for modelling occupancy and detection ["local": interior (0) or buffer (1)]; and three site covariates [mean temperature (Temp), cumulative rainfall (Precip), distance from the nearest unpaved road (DRD)] and one survey-specific covariate [sampling date (Julian date beginning at our first sampling day) to incorporate time variation] for detection. Correlation tests (Spearman and Pearson tests) were performed to investigate the collinearity between covariates in $\mathrm{R}$ ( $\mathrm{R}$ Core Team 2014); all tested correlations were weak (correlation coefficients $<0.6$ ).

A set consisting of candidate models was constructed from all possible additive combinations of up to two covariates for detection parameter $(p)$. For this set of models $\psi$ was estimated as null or with "local" covariate (Doherty et al. 2012). The most explanatory model or models was/were selected using the Akaike Information Criterion corrected for small-sample bias (AICc) (Burnham \& Anderson 2002, MacKenzie et al. 2006) and associated model weights $\left(\omega_{i}\right.$, Burnham \& Anderson 2002). This approach is considered the best method for achieving useful estimates of cumulative variable weights $\left(w_{\text {cum }}\right)$ since it allows constructing a balanced model set (Doherty et al. 2012).

We used the parametric bootstrap approach based on 10000 bootstrap resamples to evaluate the goodness of fit of global model (the most parameterized model with all additive covariates in $\psi$ and $p$ ) in program PRESENCE v.6.2 (MacKenzie \& Bailey 2004; Hines 2006). The global model is considered an adequate description of the data, implying that there is no spatial autocorrelation between sampled points, if the estimated overdispersion parameter (c) is approximately equal to one (Burnham \& Anderson 2002), which was the case here (see Results). 
In order to evaluate the sampling effort and to compare species richness between interior and buffer zone, we computed rarefaction curves with incidence data (presence/absence of native species only) using EstimateS version 9.1.0 (Colwell 2013). We analysed the randomized curve of "observed" species $\left(S_{\text {est }}\right)$ as well as the curve of "estimated" richness (first order Jackknife estimator) separately for interior and buffer zone.

\section{Results}

Our camera trap data indicated that all five selected species were using both interior and buffer zone. Collared peccary and giant anteater were mostly detected in the interior $(77 \%$ and $67 \%$ of sampling points, respectively) while maned wolf and puma were more frequent in the buffer zone $(80 \%$ and $60 \%$, respectively). Ocelots were registered at 26 sites in total, half in the interior and half in the buffer zone.

Regarding occupancy and detection modeling, the 'goodness of fit' test using the global model showed good fit with no evidence of overdispersion for those species (Table 2). From the best ranked model that contained "local" covariate for $\psi$ for each species, giant anteater had the highest occupancy probability for interior $(\psi=0.73)$, followed by ocelot $(\psi=$ 0.63 ) and collared peccary $(\psi=0.50)$ (Table 2). For these species, occupancy probabilities were numerically higher in the interior than in the buffer zone, but the difference was not strong since there was overlap between the $95 \%$ confidence intervals of the estimates for "local" covariate (Figure 3). However, for giant anteater, the overlap was smaller, indicating a higher use within the protected area (Table 2 and Figure 3). On the other hand, the second-ranked model for puma showed higher occupancy probability in the buffer $(\psi=0.64)$ than in the interior $(\psi=0.41)$, but its $95 \%$ confidence intervals overlapped, indicating that this species used both areas similarly (Table 2 and Figure 3).

Although "local" was also important for maned wolf, the best-ranked model with this covariate did not converge (Table 2) and its confidence intervals included "zero". This may have happened because maned wolf was detected by cameras trap almost four times more frequently in the buffer zone ( 24 sites) than in the interior ( 6 sites). Then, considering the best-ranked converged model with a reliable occupancy estimates $[\psi$ (local), $p(\mathrm{DRD}+\mathrm{Temp})]$, maned wolf had the highest occupancy estimate in the buffer $(\psi=0.79$; Figure 3$)$ among all species of interest in this study.

Local was the most important variable for modeling variation in detection probability for collared peccary and maned wolf ( $w_{\text {cum }}=0.86$ and $w_{\text {cum }}=0.94$, respectively). We found a negative relationship for $P$. tajacu $(\beta=-1.98 ; 95 \%$ $\mathrm{CI}=-2.84$ to -1.11$)$ and a positive relationship for $C$. brachyurus $(\beta=2.00 ; 95 \% \mathrm{CI}=1.07$ to 2.93 ) between buffer zone and detection of these species at occupied sites. For puma and ocelot, the most important variable affecting detection was "distance to the nearest unpaved road", since this covariate had a combined explanatory power of $99 \%$ for each species. For these two felids, detection was lower for camera traps located further from unpaved roads. For giant anteater, no model with covariates for detection was better ranked than the null model.

In regard to the inventory, we recorded 31 species of medium and large-sized mammals in the study area, 26 native and five exotic species. The use of multiple methods was important because some species were recorded solely by one method of survey (Table 3). Twenty-six species occurred in the interior of JES and LAES, while 25 in the buffer zone. Among native species, five were solely recorded in interior (Cavia aperea, Cuniculus paca, Didelphis albiventris, Sapajus nigritus and Tapirus terrestris) while two exotic and two natives species were observed only in the buffer zone (Bos taurus, Felis catus, Callicebus nigrifrons and Procyon cancrivorus, respectively). Considering native species that occurred both in interior and in buffer zone, 10 species were mostly recorded in interior, while six were more frequent in buffer zone (Cabassous unicinctus, Cerdocyon thous, C. brachyurus, Puma yagouaroundi, Mazama gouazoubira and Hydrochoerus hydrochaeris) (Table 3).

Considering only native mammal species recorded by camera traps $(n=21)$, the observed richness was similar between interior $(n=19)$ and buffer zone $(n=18)$, as there was overlap in the $95 \%$ confidence intervals of the resulting rarefaction curves (Figure 4). In addition, interior and buffer shared $60 \%$ of native species $(n=16)$ (Table 3). The rarefaction curves (both interior and buffer zone) did not reach asymptotes. Nevertheless, they showed a stabilization trend (Figure 4), indicating a satisfactory survey effort. The estimates of total mammal richness $\left(1^{\text {st }}\right.$ order Jackknife estimator) suggested, however, that there might be additional species in the study area that were not recorded during our sampling. Regarding this, these curves indicated that the number of additional species might be higher in buffer zone than in interior of the PA (Figure 4).

\section{Discussion}

According to our results, M. tridactyla, P. tajacu, L. pardalis and $P$. concolor all used similarly the interior and the buffer zone, when we consider the confidence intervals of the estimated occupancy parameter. The large amount of continuous native vegetation within JES and LAES (77\%), probably makes the area within their perimeters a highly favourable environment for these species for several reasons, including thermoregulation (Camilo-Alves \& Mourão 2006), shelter and feeding (Oliveira 1994, Emmons \& Feer 1997, Murray \& Gardner 1997, Medri \& Mourão 2005). However, large mammals inhabiting the Cerrado might not be able to survive in the long term solely within protected areas (Massara et al. 2012). The amount of native vegetation in buffer zone are thus important sources of additional resources for some species, and for providing dispersal routes.

Moreover, some species seem capable of using land cover types common in the buffer. The giant anteater, for example, used pine and eucalyptus plantations in the buffer zone. These production areas represent $13 \%$ of buffer and might be considered as complementary habitats, at least for this threatened species. Other authors have already found the giant anteater making extensive use of planted forests in northern Brazil (Kreutz et al. 2012, Timo et al. 2014), as well as soybean plantations and disturbed grassland in central Brazil (Shaw et al. 1987). According to some studies, forest plantations can catalyse the natural regeneration in their understory, making them more attractive habitats for wild species and contributing to biodiversity conservation in general (Viani et al. 2010).

Occurrence of mammals in buffer zones was also reported in a multi-species agroforestry system in Indonesia, where this type of land-use was identified as a good strategy to extend the habitat for mammalian populations (Salafsky 1993). This author highlights, however, that this system may not be as 
Buffer zone use by mammals in a Cerrado protected area

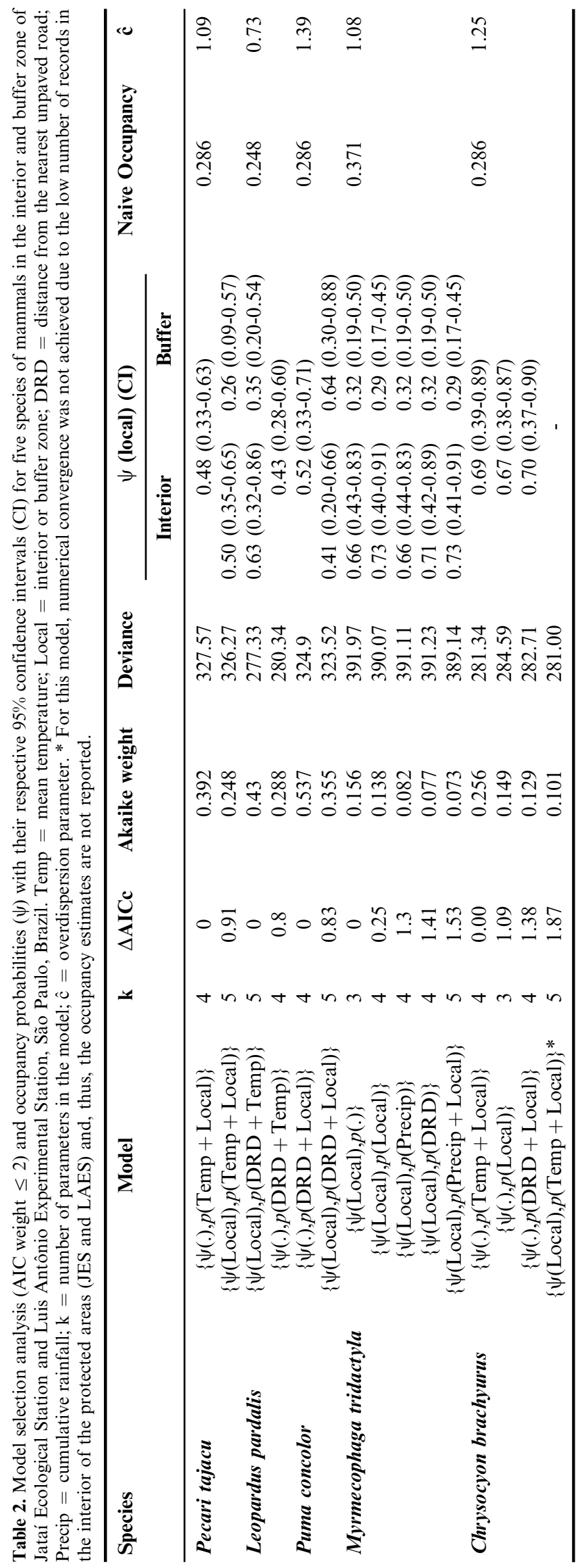




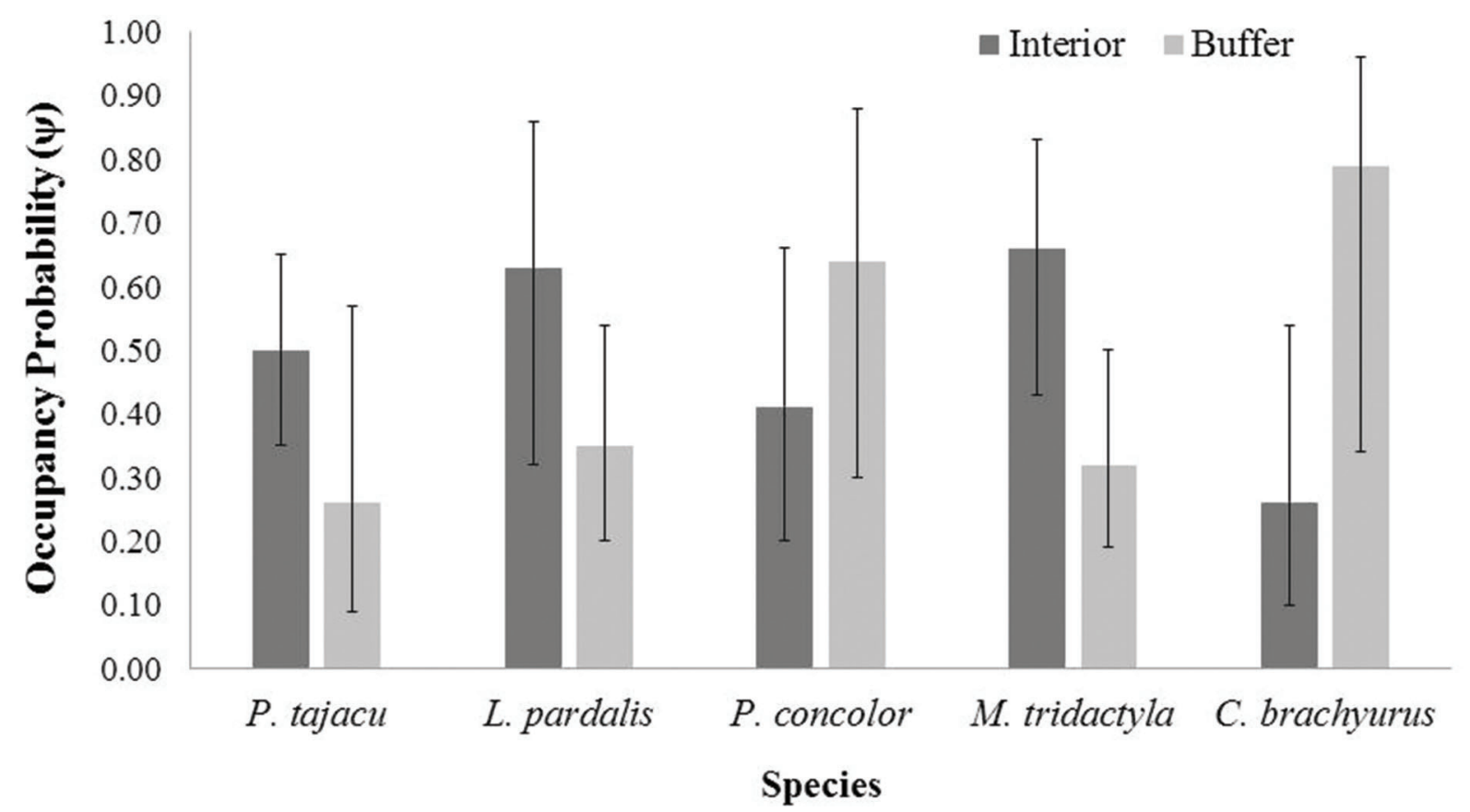

Figure 3. Occupancy estimates $(\psi)$ for five species of medium and large-sized mammals in the Jataí Ecological Station and Luiz Antônio Experimental Station interior and in the buffer zone with their respective $95 \%$ confidence intervals (vertical lines). For $C$. brachyurus, the estimates are from the ninth-ranked model [ $\psi$ (local), $p(\mathrm{DRD}+\mathrm{Temp})]$ because the best-ranked model including "local" as a covariate had no numeric convergence for the interior and the confidence interval included "zero" (see Table 2).

suitable for animals when it is not surrounding a forested core area. In Thailand, even relatively rare large mammals used a buffer zone. Nonetheless, their occurrence was negatively affected by domestic animals and human presence (Jotikapukkana et al. 2010).

Our results from the two largest carnivores, puma and maned wolf, also reinforce the importance of buffer zone, since they were mostly recorded and detected in the surrounding of the PA. As both species are wide-ranging, it is rather expected that they might use areas much larger than the protected areas. However, this finding also indicate, apart from the high capacity of movement and dispersal (Oliveira 1994, Mantovani 2001), a relatively high tolerance of these species to anthropogenic habitat alterations (Van Dyke 2008; Massara et al. 2012). These results are very interesting, because they suggest that the buffer zone, although disturbed, can still provide favorable habitat and food resources for these large carnivores. Similarly, the generalist puma and maned wolf have been recorded outside of Emas National Park, another large Cerrado protected area (Silveira 2004; Vynne et al. 2010; Vynne et al. 2014). Our results support therefore the notion that buffer zones are potential usable area for these large carnivores, corroborating other authors (Massara et al. 2012; Miotto et al. 2012).

In addition, detection probabilities for puma and maned wolf were higher in buffer zone than inside the PA, while detection of collared peccary was lower in the buffer zone. Puma and maned wolf have a high movement capacity and travel long distances (Oliveira 1994, Massara et al. 2012). Thus, their higher use of the buffer zone may increase their detection probability. On the other hand, distance from the nearest road explained better the detection of wild cats. This result is expected since felids, in general, have been detected preferentially along unpaved roads, while species such as $P$. tajacu avoid roads and have been recorded with higher frequency in forest interiors (Trolle \& Kéry 2005, Goulart et al. 2009, Srbek-Araujo \& Chiarello 2013). Moreover, although we did not assess the relative impact of poaching, the collared peccary is a traditional target in Brazil (Cullen et al. 2000), and it might also be disturbed by domestic dogs (Canis familiaris), present in human settlements that are common outside protected areas.

Records from the inventory also stressed the need for buffer zone conservation, for example through the use of biodiversity friendly agricultural practices. Whereas some species were restricted to the interior, the majority was recorded in both interior and buffer zone and others were restricted to the buffer. Our study area is currently harbouring $61.5 \%(n=24)$ of all native medium and large-sized non-arboreal mammals species that could potentially occur in the study region $(n=39)$, according to the literature. We made an important record of the lowland tapir (Tapirus terrestris; Rodrigues et al. 2014), a species threatened with extinction regionally (Bressan et al. 2009) and globally (IUCN 2014). This species had not been seen in JES for more than 50 years (Lyra-Jorge 2007) and its last sign was a skeleton found in the middle 1980's (Talamoni et al. 2000). However, apart from us, an unpublished camera trap study carried out in JES between 2009 and 2010 detected tapirs inside JES recently (Enrique Queralt, personal communication). Although this species was recorded only in the interior, it has large home-range requirements to maintain a viable population (Medici et al. 2012). For this reason, native vegetation of the buffer zone may be fundamental to its conservation. Another important record was the marsh deer, Blastocerus dichotomus, which is critically endangered in São Paulo state (Bressan et al. 2009). This deer was reintroduced in JES and surrounding areas in 1998 (Figueira et al. 2005) and 
Buffer zone use by mammals in a Cerrado protected area

Table 3. Species list of the medium and large-sized mammals observed in the Jataí Ecological Station (JES), Luiz Antônio Experimental Station (LAES) and their buffer, the record type, the local where the species was recorded (interior or buffer), the number of sites and of records of each species. Type of record: CT - camera trapping; DO - direct observation; FO - footprint; VO - vocalization. ${ }^{\mathrm{A}}$ In some, but not all photos of Dasypus spp., D. novencinctus was clearly identified, but in others the identification is possible only to the genus level; ${ }^{\mathrm{B}}$ Exotic species and ${ }^{\mathrm{C}}$ Domesticated exotic species.

\begin{tabular}{|c|c|c|c|c|c|}
\hline \multirow[t]{3}{*}{ ORDER/Family/Species } & \multirow[t]{3}{*}{ Record type } & \multicolumn{4}{|c|}{ Local } \\
\hline & & \multicolumn{2}{|c|}{ Interior } & \multicolumn{2}{|c|}{ Buffer Zone } \\
\hline & & Sites & Records & Sites & Records \\
\hline \multicolumn{6}{|l|}{ DIDELPHIMORPHIA } \\
\hline \multicolumn{6}{|l|}{ Didelphidae } \\
\hline Didelphis albiventris & $\mathrm{CT}$ & 3 & 3 & 0 & 0 \\
\hline \multicolumn{6}{|l|}{ PILOSA } \\
\hline \multicolumn{6}{|l|}{ Myrmecophagidae } \\
\hline Myrmecophaga tridactyla & $\mathrm{CT}, \mathrm{FO}, \mathrm{DO}$ & 32 & 52 & 19 & 39 \\
\hline Tamandua tetradactyla & $\mathrm{CT}, \mathrm{DO}$ & 3 & 3 & 1 & 1 \\
\hline \multicolumn{6}{|l|}{ CINGULATA } \\
\hline \multicolumn{6}{|l|}{ Dasypodidae } \\
\hline Cabassous unicinctus & CT, DO & 1 & 1 & 2 & 2 \\
\hline Dasypus spp. ${ }^{\mathrm{A}}$ & $\mathrm{CT}, \mathrm{FO}$ & 11 & 15 & 9 & 16 \\
\hline Euphractus sexcinctus & $\mathrm{CT}, \mathrm{FO}, \mathrm{DO}$ & 3 & 3 & 1 & 1 \\
\hline \multicolumn{6}{|l|}{ PRIMATES } \\
\hline \multicolumn{6}{|l|}{ Cebidae } \\
\hline Sapajus nigritus & DO & 1 & 1 & 0 & 0 \\
\hline Callicebus nigrifrons & VO & 0 & 0 & 2 & 2 \\
\hline \multicolumn{6}{|l|}{ LAGOMORPHA } \\
\hline \multicolumn{6}{|l|}{ Leporidae } \\
\hline Sylvilagus brasiliensis & $\mathrm{CT}, \mathrm{FO}, \mathrm{DO}$ & 13 & 23 & 13 & 18 \\
\hline Lepus europaeus & $\mathrm{CT}, \mathrm{FO}, \mathrm{DO}$ & 10 & 13 & 20 & 35 \\
\hline \multicolumn{6}{|l|}{ CARNIVORA } \\
\hline \multicolumn{6}{|l|}{ Canidae } \\
\hline Canis familiaris $\mathrm{C}$ & $\mathrm{CT}, \mathrm{FO}, \mathrm{DO}$ & 7 & 14 & 24 & 64 \\
\hline Cerdocyon thous & $\mathrm{CT}, \mathrm{FO}, \mathrm{DO}$ & 10 & 10 & 30 & 123 \\
\hline Chrysocyon brachyurus & $\mathrm{CT}, \mathrm{FO}, \mathrm{DO}$ & 17 & 19 & 35 & 69 \\
\hline \multicolumn{6}{|l|}{ Felidae } \\
\hline Felis catus ${ }^{\mathrm{C}}$ & $\mathrm{CT}$ & 0 & 0 & 1 & 1 \\
\hline Leopardus pardalis & $\mathrm{CT}, \mathrm{FO}$ & 15 & 29 & 14 & 34 \\
\hline Puma yagouaroundi & $\mathrm{CT}, \mathrm{FO}$ & 2 & 4 & 8 & 9 \\
\hline Puma concolor & $\mathrm{CT}, \mathrm{FO}, \mathrm{DO}$ & 22 & 53 & 22 & 45 \\
\hline \multicolumn{6}{|l|}{ Mustelidae } \\
\hline Eira barbara & $\mathrm{CT}, \mathrm{FO}, \mathrm{DO}$ & 16 & 26 & 7 & 12 \\
\hline \multicolumn{6}{|l|}{ Mephitidae } \\
\hline Conepatus semistriatus & $\mathrm{CT}, \mathrm{FO}, \mathrm{DO}$ & 13 & 17 & 13 & 19 \\
\hline Procyonidae & & & & & \\
\hline Nasua nasua & $\mathrm{CT}$ & 6 & 7 & 2 & 40 \\
\hline Procyon cancrivorus & FO & 0 & 0 & 1 & 1 \\
\hline PERISSODACTYLA & & & & & \\
\hline Tapiridae & & & & & \\
\hline Tapirus terrestris & $\mathrm{CT}, \mathrm{FO}$ & 4 & 4 & 0 & 0 \\
\hline ARTIODACTYLA & & & & & \\
\hline Tayassuidae & & & & & \\
\hline Pecari tajacu & $\mathrm{CT}, \mathrm{FO}, \mathrm{DO}$ & 30 & 245 & 10 & 36 \\
\hline Cervidae & & & & & \\
\hline Mazama gouazoubira & $\mathrm{CT}, \mathrm{FO}, \mathrm{DO}$ & 24 & 68 & 32 & 73 \\
\hline Blastocerus dichotomus & FO & 4 & 4 & 1 & 1 \\
\hline Bovidae & & & & & \\
\hline Bos taurus $C$ & $\mathrm{CT}, \mathrm{FO}, \mathrm{DO}$ & 0 & 0 & 5 & 28 \\
\hline Suidae & & & & & \\
\hline Sus scrofa ${ }^{B}$ & $\mathrm{CT}, \mathrm{FO}$ & 10 & 22 & 5 & 6 \\
\hline
\end{tabular}


Table 3. Continued.

\begin{tabular}{|c|c|c|c|c|c|}
\hline \multirow[t]{3}{*}{ ORDER/Family/Species } & \multirow[t]{3}{*}{ Record type } & \multicolumn{4}{|c|}{ Local } \\
\hline & & \multicolumn{2}{|c|}{ Interior } & \multicolumn{2}{|c|}{ Buffer Zone } \\
\hline & & Sites & Records & Sites & Records \\
\hline $\begin{array}{l}\text { RODENTIA } \\
\text { Cuniculidae }\end{array}$ & & & & & \\
\hline $\begin{array}{l}\text { Cuniculus paca } \\
\text { Caviidae }\end{array}$ & $\mathrm{CT}$ & 3 & 6 & 0 & 0 \\
\hline Cavia aperea & DO & 2 & 2 & 0 & 0 \\
\hline $\begin{array}{l}\text { Hydrochoerus hydrochaeris } \\
\text { Dasyproctidae }\end{array}$ & $\mathrm{CT}, \mathrm{DO}$ & 1 & 1 & 3 & 3 \\
\hline Dasyprocta azarae & $\mathrm{CT}, \mathrm{FO}, \mathrm{DO}$ & 19 & 74 & 5 & 13 \\
\hline
\end{tabular}

seems to be still using both interior and buffer zone. The continued presence of the marsh deer suggests, therefore, an enduring population. Hence, further investigation is necessary to ascertain current conservation status of marsh deer and lowland tapir in the region.

Considering the Management Plan of JES (Leonel et al. 2010) and previous inventories carried out in the study area (Gargaglioni et al. 1998, Talamoni et al. 2000, Lyra-Jorge 2007), some species were expected to occur but were not detected by us, such as Galictis sp., that may have not been recorded due to its swiftness and relatively small body size, and Leopardus tigrinus, that has been rarely recorded by camera traps, perhaps due to its natural rarity (Emmons \& Feer 1997). Low abundance or local extinction may also explain the lack of records of the red brocked deer (Mazama americana), since this species is vulnerable to environmental changes (Duarte et al. 2012). Species such as Ozotoceros bezoarticus, Panthera onca, Priodontes maximus and Tayassu peccary are possibly extinct locally since they have not been observed there in the last decades (Gargaglioni et al. 1998, Bressan et al. 2009, Duarte et al. 2012, Keuroghlian et al. 2013). They are very sensitive to habitat loss and fragmentation, disappearing from degraded areas (Chiarello 1999, Cullen et al. 2000, Morato et al. 2013).

We consider that our sampling effort was sufficient to record most of the common and abundant species and possibly some of the rarest ones as well, still occurring in the study area. Although generalisations about this are tricky, camera trapping studies carried out elsewhere suggest that rare species begin to "appear" in inventories after sampling efforts in the range of 1000-2000 camera trap days (Tobler et al. 2008). However, although the buffer area is almost four times larger than the interior, the sampling effort was roughly the same for both areas. This difference may, therefore, explain why the curve of total estimated richness for the interior tended to stabilize, while that of the buffer did not. This is in accord with the classical species-area relationship (MacArthur \& Wilson 1967), which indicates that larger sampled areas should hold higher diversity.

This species-area relationship could partially explain the fact that buffer zone was almost as rich as the interior of the PA. This similarity probably also results from the close proximity of JES, which may act as a source of individuals, and from the existence of a large floodplain (the Mogi-Guaçu river floodplain that has 4064 ha) in the buffer zone. Moreover, despite being proportionally less covered by native vegetation than the PA, the buffer zone has approximately 5260 ha of native vegetation distributed in several fragments. These remnants of the buffer zone are close to or structurally linked to the riparian vegetation distributed along the Mogi-Guaçu River. The preservation of these riparian forests is, therefore, of utmost importance, considering the overwhelming predominance of sugarcane plantations in the buffer area.
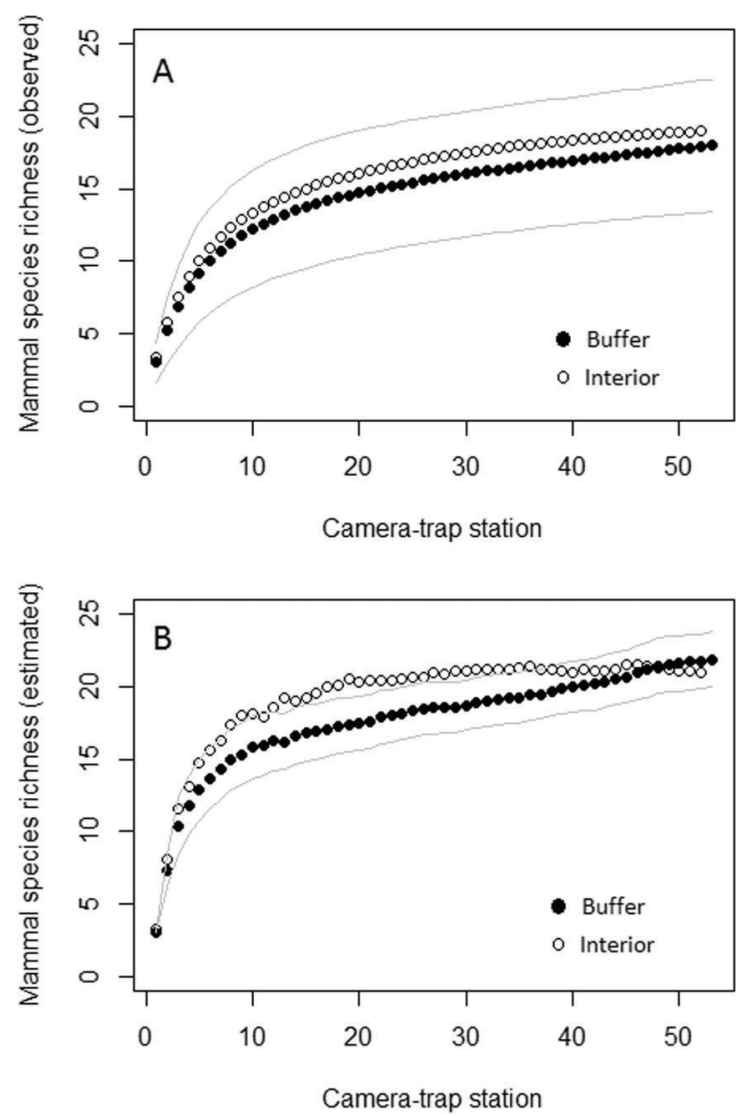

Figure 4. A. Rarefaction curves for observed richness of native species recorded by camera trapping in the Jataí Ecological Station (JES) and Luiz Antônio Experimental Station (LAES) interior and buffer zone. B. Estimated richness of native species recorded by camera trapping in JES and LAES interior and buffer zone by the Jackknife $1^{\text {st }}$ order estimator. The grey lines represent the $95 \%$ confidence intervals for the observed richness in the interior and the estimated richness in the buffer zone respectively. 
Overall, our study contributes with relevant information that highlight the importance of buffer zones for wildlife. As more biological data are obtained, the closer we get to a biologically sound extend of a buffer zone (Tambosi 2008, Alexandre et al. 2010, Massara et al. 2012). Definitions about this should be clearly stated in the Management Plan of protected areas, as stated by law 9985/2000 (Brasil, 2000). If the PA does not have a Management Plan, the CONAMA Resolution $n^{\circ} 428 / 2010$ states that the buffer zone should be at least three kilometres wide. This extent is very close to the buffer zone we assessed, since our camera traps were located up to $2.6 \mathrm{~km}$ from the perimeter of the closest PA. We did not expect finding comparable levels of mammal species richness in a buffer zone heavily dominated by intensive agriculture and silviculture. Furthermore, as we discussed above, this minimum extent was indeed very important for the set of species we studied more closely, including threatened ones, as the differences in occupancy status between interior and buffer zone were less contrasting than we anticipated. Put together, these findings might be seen as good news for the conservation of our study species. In addition, our results may help managers of protected areas not only to delimit the range of buffer zone, but also to define what type of activity might be allowed inside it.

Nevertheless, we stress the need for a cautionary look at these findings. What we got here was just an instantaneous snapshot of a truly dynamic process, of which we still have a lot to study. Is the buffer zone by itself able to sustain "independent" mammal populations in the long term? Or, alternatively, is it a sink area for individuals coming from inside the PA? What portion of the "resident" populations living inside JES and LAES also inhabits (and perhaps is dependent from), the surroundings of these PA? How occupancy and detection vary at different distances from PA? These, of course, are key questions that we must start addressing as soon as possible to qualify our findings. Notwithstanding these, our main findings do highlight the need of researchers, rural inhabitants and managers of protected areas, to urgently start looking more closely and deeply to the role played by buffer zones, and to the need to effectively implement management strategies to these important zones.

\section{Acknowledgments}

This study was funded by a research grant from the São Paulo Research Foundation (FAPESP - 2011/22449-4). We thank the International Paper do Brasil, the Universidade de São Paulo, Instituto Florestal and Fundação Florestal of the state of São Paulo for logistical support. The Instituto Geográfico e Cartográfico do Estado de São Paulo gently made available maps and ortophotomosaics. We are indebted to Dr. Aurelio Fontes for its assistance with Geographic Information Systems, spatial analyses and mapping.

\section{References}

ALEXANDRE, B., CROUZEILLES, R. \& GRELLE, C.E.V. 2010. How Can We Estimate Buffer Zones of Protected Areas? A Proposal Using Biological Data. Natureza \& Conservação 8(2): 165-170.

BAILEY, L.L., SIMONS, T.R. \& POLLOCK, K.H. 2004. Estimating site occupancy and species detection probability parameters for terrestrial salamanders. Ecological Applications v. 14, p. 692-702, http://dx.doi.org/10.1890/03-5012

BECKER, M. \& DALPONTE, J.C. 1999. Rastros de mamíferos silvestres brasileiros: um guia de campo. 2 ed., Brasília: Ed. UnB; Ed. IBAMA, DF, Brazil.

BORGES, P.A.L. \& WALFRIDO, M.T. 2004. Guia de rastros e outros vestígios de mamíferos do Pantanal. Corumbá: Embrapa Pamtanal, MS, Brazil.

BRASIL. SNUC. Lei $\mathrm{N}^{\circ}$ 9.985, de 18 de julho de 2000. Institui o Sistema Nacional de Unidades de Conservação da Natureza e dá outras providências.

BRESSAN, P.M., KIERULFF, M.C.M. \& SUGIEDA, A.M. 2009. Fauna Ameaçada de Extinção no estado de São Paulo - Vertebrados; São Paulo: Fundação Parque Zoológico de São Paulo: Secretaria do Meio Ambiente.

BURNHAM, K.P. \& ANDERSON, D.R. 2002. Model selection and multimodel inference: A practical information-theoretic approach. 2ed. Springer-Verlag, New York, USA.

CAMILO-ALVES, C.S.P. \& MOURÃO, G. 2006. Responses of a specialized insectivorous mammal (Myrmecophaga tridactyla) to variation in ambient. Biotropica 38(1): 52-56.

CARVALHO Jr., O. \& LUZ, N.C. 2008. Pegadas: Série boas práticas, v. 3, 64p. Belém: EDUFPA, PA, Brazil.

CEPAGRI. 2014. Clima dos municípios paulistas. www.cpa.unicamp.br/ outrasinformacoes/clima_muni_279.html (last access 17/03/2016).

CHAPE, S., HARRISON, J., SPALDING, M. \& LYSENKO, I. 2005. Measuring the extent and effectiveness of protected areas as an indicator for meeting global biodiversity targets. Philos. Trans. R. Soc. Lond. 360 p. 443-455, http://dx.doi.org/10.1098/rstb.2004.1592

CHIARELLO, A.G. 1999. Effects of fragmentation of the Atlantic forest on mammal communities in south-eastern Brazil. Biological Conservation v. 89, p. 71-82, http://dx.doi.org/10.1016/S0006-3207 (98)00130-X

COLWEL, R.L. 2013. Estimate S: Statistical estimation of species richness and shared species from samples. Version $9.1 \mathrm{http} / / /$ viceroy.eeb.uconn.edu/estimates/ (last access 17/03/2016).

COVE, M.V. 2011. Occupancy Modelling of Medium and Large Mammal Diversity in a Central American Biological Corridor. Master of Science Thesis. Department of Biology and Earth Science University of Central Missouri.

CULLEN, L. Jr., BODMER, R.E. \& VALLADARES-PADUA, C. 2000. Effects of hunting in habitat fragments of the Atlantic forest, Brazil. Biological Conservation, v. 95, p. 49-56, http://dx.doi.org/ 10.1016/S0006-3207(00)00011-2

DIRZO, R., YOUNG, H.S., GALETTI, M., CEBALlOS, G., ISAAC, N.J.B. \& COLLEN, B. Defaunation in the anthropocene. Science, 345 (2014), pp. 401-406, http://dx.doi.org/10.1126/science. 1251817

DOHERTY, P.F., WHITE, G.C. \& BURNHAM, K.P. 2012. Comparison of model building and selection strategies. Journal of Ornithology 152 (Supplement 2):317-323, http://dx.doi.org/10.1007/ s10336-010-0598-5

DUARTE, J.M.B., VOGLIOTTI, A., ZANETTI, E.S., OLIVEIRA, M.L., TIEPOLO, L.M., RODRIGUES, L.F., ALMEIDA, L.B. \& BRAGA, F.G. 2012. Avaliação do Risco de Extinção do Veadocampeiro Ozotoceros bezoarticus Linnaeus, 1758, no Brasil. Biodiversidade Brasileira, Ano II, v. 3, p. 20-32.

EISENBERG, J.F. \& REDFORD, K.H. 1999. Mammals of the Neotropics: The Central Neotropics. Vol.3. Chicago and London, University of Chicago Press, 609p.

EMMONS, L.H. \& FEER, F. 1997. Neotropical Rainforest Mammals: a field guide. 2nd edition, Chicago and London, University of Chicago Press, 307p.

ESRI. 2002. Environmental Systems Research Institute, Inc. ArcGIS Professional GIS, versão 10.1. CA.

FIGUEIRA, C.J.M., PIRES, J.S.R., ANDRIOLO, A., COSTA, M.J.R.P. \& DUARTE, J.M.B. 2005. Marsh deer (Blastocerus dichotomus) reintroduction in the Jataí Ecological Station (Luis Antônio-SP): 
Spatial preferences. Brazil. J. Biol., 65(2), 263-270, http://dx.doi.org/ 10.1590/S1519-69842005000200009

GARGAGLIONI, L.H., BATALHÃO, M.E., LAPENTA, M.J., CARVALHO, M.F., ROSSI, R.V. \& VERULI, V.P. 1998. Mamíferos da Estação Ecológica de Jataí, Luiz Antônio, São Paulo. Pap. Avulsos Zool. 40(17): 267-287.

GOULART, F.V.B., CÁCERES, N.C., GRAIPEL, M.E., TORTATO, M.A., GHIZONI-Jr., I.R. \& OLIVEIRA-SANTOS, L.G.R. 2009. Habitat selection by large mammals in a Southern Brazilian Atlantic Forest. Mamm. biol., v. 74, p. 182-190.

HINES, J.E. 2006. PRESENCE - Software to estimate patch occupancy and related parameters. USGS-Patuxent Wildlife Research Center, Maryland. http://www.mbr-pwrc.usgs.gov/software/presence.html (last access on 17/03/2016).

HJERT, C-J. 2006. People vs. Wildlife: Buffer zones to integrate wildlife conservation and development? Södertörns högskola Miljö-och Utvecklingsprogrammet C-uppsats 10 poäng. Södertörns högskola University College.

IBGE (INSTITUTO BRASILEIRO DE GEOGRAFIA E ESTATÍSTICA). 2010. Indicadores de Desenvolvimento Sustentável. Estudos e Pesquisas. Informações geográficas número sete. http://www. ibge.gov.br (last access on 17/03/2016).

IUCN. 2014. Red List. http://www.iucnredlist.org/initiatives/mammals/ analysis. (last access on 17/03/2016).

JOTIKAPUKKANA, S., BERG, A., PATTANAVIBOOL, A. 2010. Wildlife and human use of buffer zone areas in a wildlife sanctuary. Wildlife Research 37 (6): 466-74, http://dx.doi.org/10.1071/ WR09132

KASPER, C.B., FONTOURA-RODRIGUES, M.L. DA, CAVALCANTI, G.N., FREITAS, T.R.O. DE, RODRIGUES, F.H.G., OLIVERA, T.G. \& EIZIRIK, E. 2009. Recent advances in the knowledge of Molina's Hog-nosed Skunk Conepatus chinga and Striped Hog-nosed Skunk C. semistriatus in South America. Small Carnivore Conservation, v. 41 , p. $25-28$.

KEUROGHLIAN, A., DESBIEZ, A., REYNA-HURTADO, R., ALTRICHTER, M., BECK, H., TABER, A. \& FRAGOSO, J.M.V. 2013. Tayassu pecari. The IUCN Red List of Threatened Species.

KLINK, C.A. \& MACHADO, R.B. 2005. Conservation of the Brazilian Cerrado. Conservation Biology, v. 19, No 3, p. 707-713, http://dx.doi.org/10.1111/j.1523-1739.2005.00702.x

KREUTZ, K., FISCHER, F. \& LINSENMAIR, K.E. 2012. Timber plantations as favourite habitat for giant anteaters. Mammalia, v. 76, n. 2, p. 137-142, http://dx.doi.org/10.1515/mammalia-2011-0049

LEONEL, C., THOMAZIELLO, S. \& OLIVEIRA, E.D. 2010. Plano de Manejo da Estação Ecológica do Jataí - SP. 334 p.

LYNAGH, F.M. \& URICH, P.B. 2002. A critical review of buffer zone theory and practice: A Philippine case study. Soc. Natural Resources, 15: 129-145, http://dx.doi.org/10.1080/089419202753403319

LYRA-JORGE, M.C. 2007. Avaliação de qualidade de fragmentos de cerrado e floresta semidecíduas na região da bacia do rio MogiGuaçú com base na ocorrência de carnívoros. Tese de Doutorado, Instituto de Biociências, Universidade de São Paulo, São Paulo.

MACARTHUR, R.H. \& WILSON E.O. 1967. The Theory of Island Biogeography, Princeton University Press, Princeton.

MACKENZIE, D.I. \& BAILEY, L. 2004. Assessing the fit of site occupancy models. Journal of Agricultural, Biological and Environmental Statistics 9:300-318, http://dx.doi.org/10.1198/108571104X3361

MACKENZIE, D.I., NICHOLS, J.D., LACHMAN, G.B., DROEGE, S., ROYLE, J.A. \& LANGTIMM, C.A. 2002. Estimating site occupancy rates when detection probabilities are less than one. Ecology v. 83, p. 2248-2255, http://dx.doi.org/10.1890/0012-9658 (2002)083[2248:ESORWD]2.0.CO;2

MACKENZIE, D.L., NICHOLS, J.D., ROYLE, J.A., POLLOCK, K.H., BAILEY, L. \& HINES, J.E. 2006. Occupancy Estimation and Modeling - Inferring Patterns and Dynamics of Species Occurrence, 1st Ed., Elsevier, EUA.

MAMEDE, S.B. \& ALBO, C.J.R. 2008. Impressões de cerrado e pantanal. $2^{\mathrm{a}}$ ed. Corumbá, MS, Brazil.
MAMMALIAN SPECIES. American Society of Mammalogists. Online Journals. http://www.asmjournals.org/loi/mmsp (last access on $17 / 03 / 2016$ )

MANTOVANI, J.E. 2001. Telemetria convencional e via satélite na determinação da área de vida de três espécies de carnívoros da região nordeste do estado de São Paulo. Tese de Doutorado, Universidade Federal de São Carlos, São Carlos.

MASSARA, R.L., PASCHOAL, A.M., DE O., HIRSCH, A. \& CHIARELLO, A.G. 2012. Diet and habitat use by maned wolf outside protected areas in eastern Brasil. Tropical Conservation Science 5(3): 284-300.

MEDICI, E.P., FLECHER, K., BEISIEGEL, B.M., KEUROGHLIAN, A., DESBIEZ, A.L.J., GATTI, A., PONTES, A.R.M., CAMPOS, C.B., TÓFOLI, C.F., JUNIOR, E.A.M., AZEVEDO, F.C., PINHO, G.M., CORDEIRO, J.L.P., JUNIOR, T.S.S., MORAIS, A.A., MANGINI, P.R., RODRIGUES, L.F. \& ALMEIDA, L.B. 2012. Avaliação do risco de extinção da Anta brasileira, Tapirus terrestris, no Brasil. In: Numero temático: Avaliação do Estado de Conservação dos Ungulados, Biodiversidade Brasileira Ano II, n 3, p. 103-116.

MEDRI, Í.M. \& MOURÃO, G. 2005. Home range of giant anteaters (Myrmecophaga tridactyla) in the Pantanal wetland, Brazil. Journal of Zoology 266 (4): 365-375, http://dx.doi.org/10.1017/S0952836905007004

MIOTTO, R.A., CERVINI, M., BEGOTTI, R.A. \& GALETTI Jr., P.M. 2012. Monitoring a Cougar (Puma concolor) Population in a Fragmented Landscape in Southeast Brazil. Biotropica 44(1) p. 98-104, http://dx.doi.org/10.1111/j.1744-7429.2011.00772.x

MIRANDA, J.M.D., MORO-RIOS, R., SILVA-PEREIRA, J.E. \& PASSOS, F.C. 2009. Guia ilustrado: Mamíferos da Serra de São Luiz do Purunã. Manuais de campo USEB - 12. Pelotas, RS, Brazil.

MORATO, R.G., BEISIEGEL, B. de M., RAMALHO, E.E., CAMPOS, C.B de, BOULHOSA, R.L.P. 2013. Avaliação do risco de extinção da Onça-pintada Panthera onca (Linnaeus, 1758) no Brasil. Avaliação do Estado de Conservação dos Carnívoros. Instituto Chico Mendes de Conservação da Biodiversidade - ICMBio, p. 122-132.

MORO-RIOS, R.E., SILVA-PEREIRA, J.E., SILVA, P.W.E., MOURA-BRITTO, M. DE, NOGAROLI D. \& PATROCÍNIO, M. 2008. Manual de rastros da Fauna Paranaense. Curitiba: Instituto Ambiental do Paraná. 70 p. 112 il.

MORSELLO, C. 2001. Áreas protegidas públicas e privadas: seleção e manejo. São Paulo: Annablume, FAPESP, 1 ed. 343 p.

MURRAY, J.L. \& GARDNER, G.L. 1997. Leopardus pardalis. Mammalian Species, 548, 1-10, http://dx.doi.org/10.2307/3504082

MYERS, N., MITTERMEIER, R.A., MITTERMEIER, C.G., FONSECA, G.A.B. \& KENT, J. 2000. Biodiversity hotspots for conservation priorities. Nature 403 p. $853-858$, http://dx.doi.org/ $10.1038 / 35002501$

NICHOLSON, J.M. \& VAN MANEN, F.T. 2009. Using occupancy models to determine mammalian responses to landscape changes. Integrative Zoology 4 p. 232-239, http://dx.doi.org/10.1111/j.17494877.2009.00159.x

O'CONNELL Jr., A.F., TALANCY, N.W., BAILEY, L.L., SAUER, J.R., COOK, R. \& GILBERT, A.T. 2006. Estimating Site Occupancy and Detection Probability Parameters for Meso- and Large Mammals in a Coastal Ecossystem. Journal of Wildlife Management, 70(6) p. 1625-1633, http://dx.doi.org/10.2193/0022-541X(2006)70[1625: ESOADP]2.0.CO;2

O'CONNELL, A.F., NICHOLS, J.D. \& KARANTH, K.U. Camera Traps in Animal Ecology: Methods and Analyses. Springer, 271 p. 2011.

OLIVEIRA, T.G de. 1994. Neotropical Cats: Ecology and Conservation. São Luís: Edufma, 244 p.

PAGLIA, A.P., da FONSECA, G.A.B., RYLANDS, A.B., HERMANN, G., AGUIAR, L.MS., CHIARELLO, A.G., LEITE, Y.L.R., COSTA, L.P., SICILIANO, S., KIERULFF, M.C.M., MENDES, S.L., TAVARES, V. DA C., MITTERMEIER, R.A., PATTON, J.L. 2012. Annotated Checklist of Brazilian Mammals $2^{\text {nd }}$ Edition. Occasional Papers in Conservation Biology. Occasional paper $n^{\circ}$ 6. Conservação Internacional do Brasil. Belo Horizonte, MG, Brazil. 
R CORE TEAM. 2014. R: A language and environment for statistical computing. R Foundation for Statistical Computing, Vienna, Austria. URL http://www.R-project.org/.

RODRIGUES, T.F., PAOLINO, R.M., VERSIANI, N.F., SALVADOR, N.A.P., OLIVEIRA, E.M. DE, CHIARELLO, A.G. 2014.The lowland tapir Tapirus terrestris is back to the largest protected area of Cerrado in the state of São Paulo, Brazil. Tapir Conservation Newsletter v. 23, n. 32 , p. 5-9.

SALAFSKY, N. 1993. Mammalian Use of a Buffer Zone Agroforestry System Bordering Gunung Palung National Park, West Kalimantan, Indonesia. Conservation Biology v. 7, n. 4, p. 928-933, http://dx.doi.org/10.1046/j.1523-1739.1993.740928.x

SHAW, J.H., MACHADO-NETO, J. \& CARTER, T.S. 1987. Behavior of free-living giant anteater (Myrmecophaga tridactyla). Biotropica Washington, 3(19): 255-259, http://dx.doi.org/10.2307/2388344

SCHIPPER, J., CHANSON, J., CHIOZZA, F., COX, N., HOFFMANN, M., KATARIYA, V., LAMOREUX, J., RODRIGUES, A.S.L., STUART, S.N., TEMPLE, H.J., BAILLIE, J.E.M., BOITANI, L., LACHER, T.E., MITTERMEIER, R.A., SMITH, A.T., ABSOLON, D., AGUIAR, J.M., AMORI, G., BAKKOUR, N., BALDI, R.A., BERRIDGE, R.J., BIELBY, J., BLACK, P.A., BLANC, J.J., BROOKS, T.M., BURTON, J.A., BUTYNSKI, T.M., CATULLO, G., CHAPMAN, R., COKELISS, Z., COLLEN, B., CONROY, J., COOKE, J.G., DA FONSECA, G.A.B., DEROCHER, A.E., DUBLIN, H.T., DUCKWORTH, J.W., EMMONS, L., EMSLIE, R.H., FESTA-BIANCHET, M., FOSTER, M., FOSTER, S.N., GARSHELIS, D.L., GATES, C., GIMENEZ-DIXON, M., GONZALEZ, S., GONZALEZ-MAYA, J.F., GOOD, T.C., HAMMERSON, G., HAMMOND, P.S., HAPPOLD, D., HAPPOLD, M., HARE, J., HARRIS, R.B., HAWKINS, C.E., HAYWOOD, M., HEANEY, L., HEDGES, S., HELGEN, K.M., HILTON-TAYLOR, C., HUSSAIN, S.A., ISHII, N., JEFFERSON, T.A., JENKINS, R.K.B., JOHNSTON, C.H., KEITH, M., KINGDON, J., KNOX, D., KOVACS, K.M., LANGHAMMER, P., LEUS, K.M., LEWISON, R., LICHTENSTEIN, G., LOWRY, L.F., MACAVOY, Z., MACE, G.M., MALLON, D.P., MASI, M., MCKNIGHT, M.W., MEDELLÍN, R., MEDICI, P., MILLS, G., MOEHLMAN, P.D., MOLUR, S., MORA, A.E., NOWELL, K., OATES, J.F., OLECH, W., OLIVER, W.L.R., OPREA, M., PATTERSON, B., PERRIN, W.F., POLIDORO, B.A., POLLOCK, C., POWEL, A., PROTAS, Y., RACEY, P.A., RAGLE, J., RAMANI, P., RATHBUN, G., REEVES, R.R., REILLY, S.B., REYNOLDS III, J.E., RONDININI, C., RULLI, M., RYLANDS, A.B., SAVINI, S., SCHANK, C.J., SECHREST, W., SELF-SULLIVAN, C., SHOEMAKER, A., SILlERO-ZUBIRI, C., SILVA, N., SMITH, D.E., SRINIVASULU, C., STEPHENSON, P.J., VAN STRIEN, N., TALUKDAR, B.K., TAYLOR, B.L., TIMMINS, R., TIRIRA, D.G., TOGNELLI, M.F., TSYTSULINA, K., VEIGA, L.M., VIE, J.-C., WILLIAMSON, L., WYATT, S.A., XIE, Y. \& YOUNG, B.E. 2008. The Status of the World's Land and Marine Mammals: Diversity, Threat, and Knowledge. Science 322: 225-230, http://dx.doi.org/10.1126/ science. 1165115

SILVEIRA, L. 2004. Ecologia Comparada da Onça-pintada (Panthera onca) e Onça-Parda (Puma concolor) no Cerrado e Pantanal. Ph.D. thesis, Universidade de Brasília, Brasília, Brazil. 240p.

SRBEK-ARAUJO, A.C. \& CHIARELLO, A.G. 2013. Influence of camera-trap sampling design on mammal species capture rates and community structures in southeastern Brazil. Biota Neotropica 13(2): 51-62: http://www.biotaneotropica.org.br/v13n2/en/abstract?article + bn02013022013, http://dx.doi.org/10.1590/S1676-06032013000200005

TALAMONI, S.A., MOTTA-JUNIOR, J.C. \& DIAS, M.M. 2000. Fauna de mamíferos da Estação Ecológica de Jataí e da estação Experimental de Luís Antônio in: Santos, J.E. \& Pires, J.S.R. (eds.) Estação Ecológica de Jataí. Volume I. São Carlos: RIMA Editora, $346 \mathrm{pp}$.

TAMBOSI, L.R. 2008. Análise da paisagem no entorno de três unidades de conservação: subsídios para a criação da zona de amortecimento. Dissertação de Mestrado, Instituto de Biociências, Universidade de São Paulo, São Paulo.

TIMO, T.P.C., LYRA-JORGE, M.C., GHELER-COSTA, C. \& VERDADE, L.M. 2014. Effect of the plantation age on the use of Eucalyptus stands by medium to large-sized wild mammals in south-eastern Brazil. iForest-Biogeosciences and Forestry, 551, http://dx.doi.org/10.3832/ifor1237-008

TOBLER, M.W., CARRILLO-PERCASTEGUI, S.E., PITMAN, R.L., MARES, R. \& POWELL, G. 2008. An evaluation of camera traps for inventorying large- and medium-sized terrestrial rainforest mammals. Animal Conservation, v. 11, p. 169-178, http://dx.doi.org/10.1111/ j.1469-1795.2008.00169.x

TOPPA, R.H. 2004. Estrutura e diversidade florística das diferentes fisionomias de Cerrado e suas correlações com o solo na Estação Ecológica de Jataí, Luiz Antônio, SP. Tese de Doutorado, Universidade Federal de São Carlos, São Carlos.

TROLLE, M. \& KÉRY, M. 2005. Camera trap study of ocelot and other secretive mammals in the northern Pantanal. Mammalian, 69 (3-4): 405-412, http://dx.doi.org/10.1515/mamm.2005.032

VAN DER MEER, E., RASMUSSEN, G.S.A. \& FRITZ, H. 2015. Using an energetic cost-benefit approach to identify ecological traps: the case of the African wild dog. Animal Conservation, v. 18 (4): p. 359-366, http://dx.doi.org/10.1111/acv.12182

VAN DYKE, F., 2008. Conservation Biology. Foundations, Concepts, Applications. Springer Science + Business Media B.V., Dordrecht.

VIANI, R.A.G., DURIGAN, G. \& MELO, A.C.G. 2010. A regeneração natural sob plantios florestais: desertos verdes ou redutos de biodiversidade? Ciência Florestal 20(3): 533-552.

VITALLI, P.L., ZAKIA, M.J.B. \& DURIGAN, G. 2009. Considerações sobre a legislação correlata à zona-tampão de unidades de conservação no Brasil. Revista Ambiente \& Sociedade 12(1) p. $67-82$.

VYNNE, C. 2010. Landscape use by wide-ranging mammals in the Brazilian Cerrado. PhD dissertation, University of Washington.

VYNNE, C., BOOTH, R.K. \& WASSER, S.K. 2014. Physiological implications of landscape use by free-ranging maned wolves (Chrysocyon brachyurus) in Brazil.

XAVIER, A.F., BOLZANI, B.M. \& JORDÃO, S. 2008. Unidades de Conservação da Natureza no estado de São Paulo in: Diretrizes para a Conservação e Restauração da Biodiversidade no estado de São Paulo. Secretaria do Meio Ambiente, São Paulo, Brasil.

WATSON, J.E.M., DUDLEY, N., SEGAN, D.B. \& HOCKINGS, M. 2014. The performance and potential of protected areas. Nature, v. 515 , p. $67-73$, http://dx.doi.org/10.1038/nature13947

WHITE, G.C. \& BURNHAM, K.P. 1999. Program MARK: survival estimation from populations of marked animals. Bird study 46 p. 120-138, http://dx.doi.org/10.1080/00063659909477239 